\title{
Sediment Deposition and Erosion in South San Francisco Bay, California from 1956 to 2005
}

By Bruce Jaffe and Amy Foxgrover

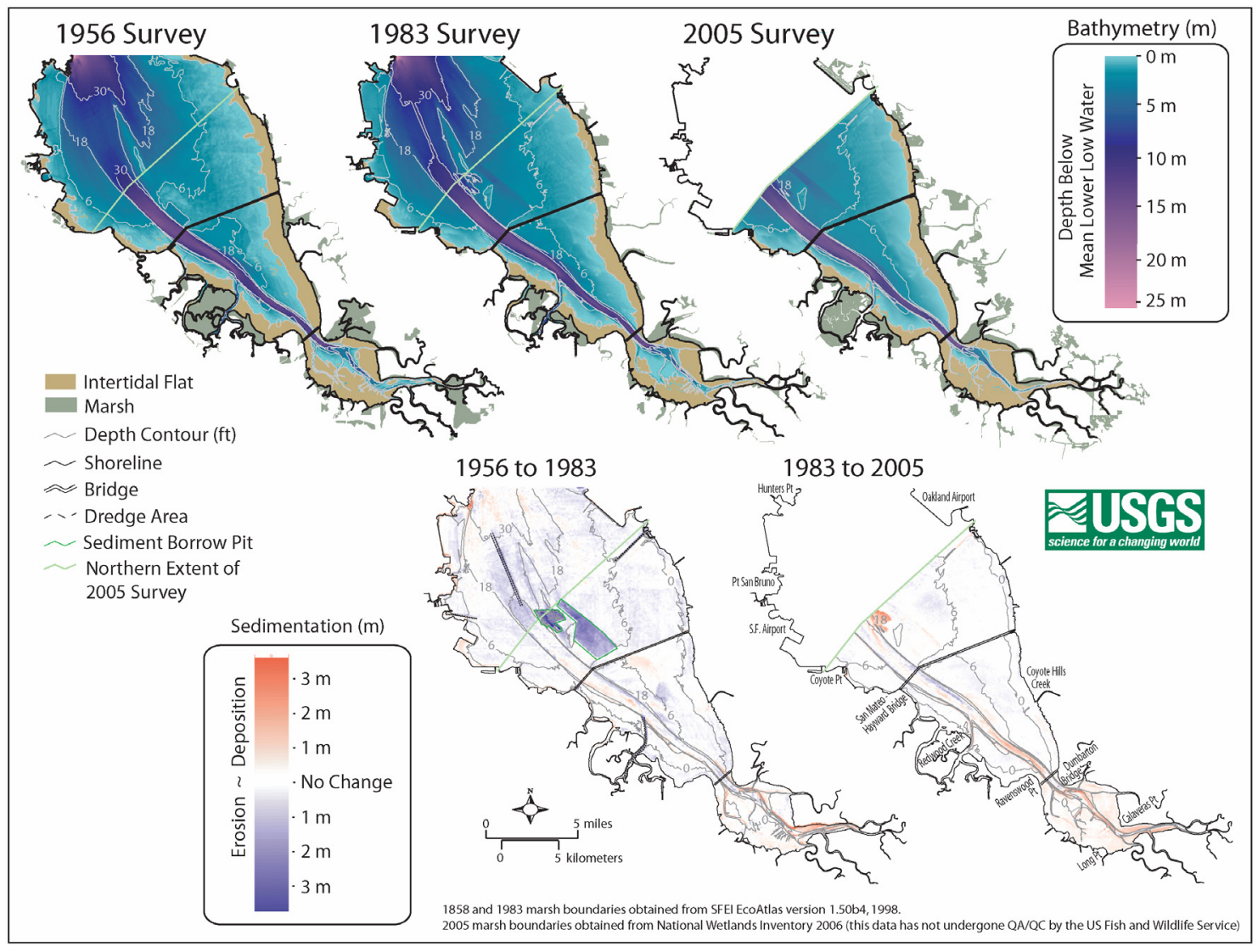

Open-File Report 2006-1287

U.S. Department of the Interior

U.S. Geological Survey 


\section{U.S. Department of the Interior \\ Dirk Kempthorne, Secretary}

\section{U.S. Geological Survey \\ P. Patrick Leahy, Acting Director}

U.S. Geological Survey, Reston, Virginia 2006

Revised and reprinted: 2006

For product and ordering information:

World Wide Web: http://www.usgs.gov/pubprod

Telephone: 1-888-ASK-USGS

For more information on the USGS - the Federal source for science about the Earth, its natural and living resources, natural hazards, and the environment:

World Wide Web: http://www.usgs.gov

Telephone: 1-888-ASK-USGS

Suggested citation:

Jaffe, B.E. and Foxgrover, A.C., 2006, Sediment Deposition and Erosion in South San Francisco Bay, California from 1956 to 2005: U.S. Geological Survey Open-File Report 2006-1287, 24 p.

[URL: http://pubs.usgs.gov/of/2006/1287]

Any use of trade, product, or firm names is for descriptive purposes only and does not imply endorsement by the U.S. Government.

Although this report is in the public domain, permission must be secured from the individual copyright owners to reproduce any copyrighted material contained within this report. 


\section{Front Cover:}

Preliminary maps of bathymetry, intertidal flat, tidal marsh and deposition and erosion in South San Francisco Bay from 1956 to 2005. 


\section{Contents}

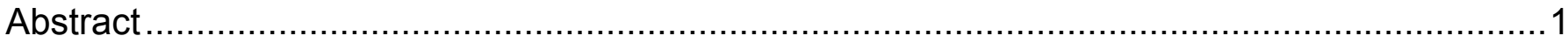

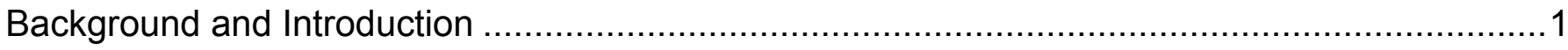

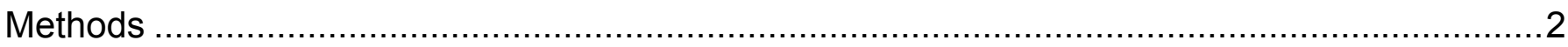

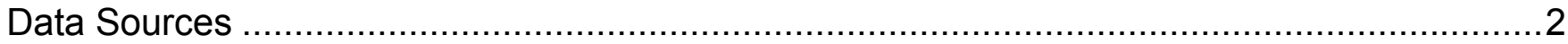

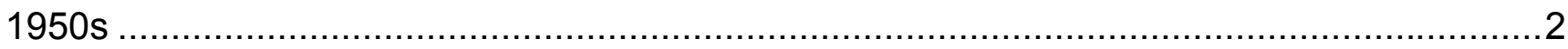

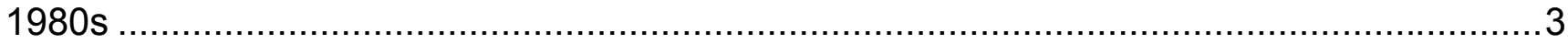

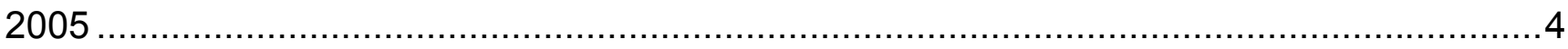

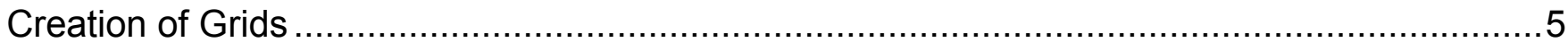

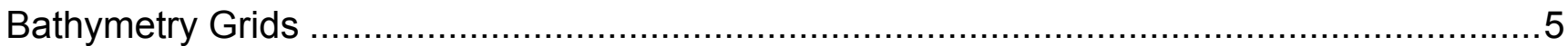

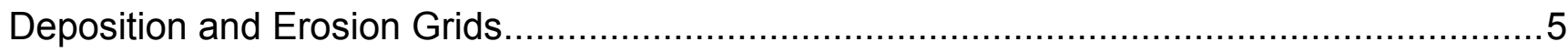

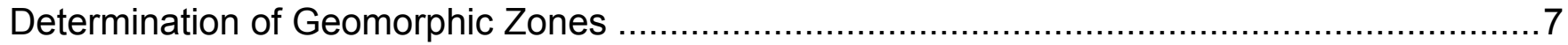

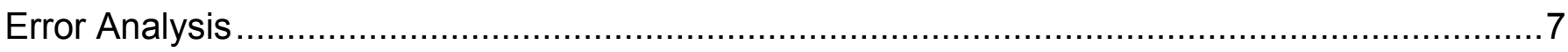

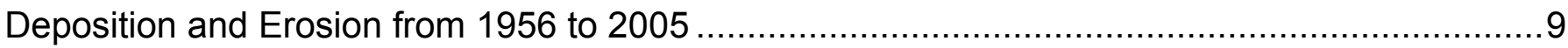

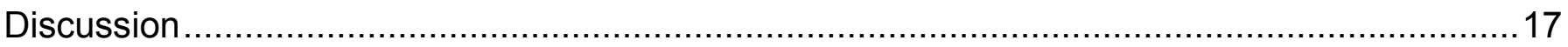

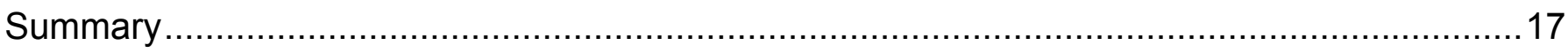

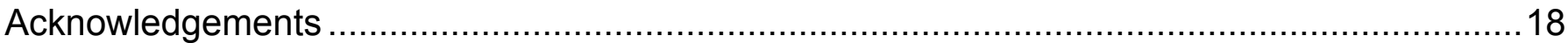

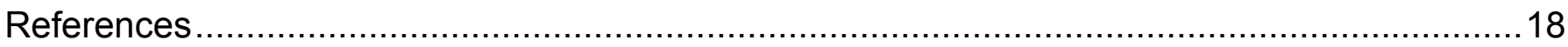

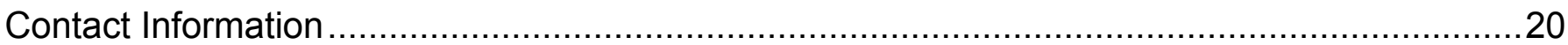




\title{
Sediment Deposition and Erosion in South San Francisco Bay, California from 1956 to 2005
}

\author{
By Bruce Jaffe and Amy Foxgrover
}

\section{Abstract}

Sediment deposition and erosion in South San Francisco Bay from 1956 to 2005 was studied by comparing bathymetric surveys made in 1956, 1983, and 2005. From 1956 to 1983, the region was erosional. In contrast, from 1983 to 2005, the region was depositional. Analysis of subregions defined by depth, morphology and location revealed similarities in behavior during both the erosional and depositional periods. During the entire period of the study, there was net erosion in the shallows $(<1 \mathrm{~m}$ depth) on the eastern shore of the bay north of the Dumbarton Bridge and net deposition in the region south of Dumbarton Bridge. The rates, however, reflected the sediment regime of each time period. Erosional areas were less erosional during the period with net deposition and depositional zones were more depositional. The cause for the increase in deposition from 1983 to 2005 is unknown, but could be related to an increase in sediment supply from Central Bay. The patterns of deposition and erosion and the change in rates are consistent with an increase in sediment supply from the north, as would occur if the supply from Central Bay increased from1956-1983 to 1983-2005. Additional research is needed to fully understand why South San Francisco Bay became depositional from 1983 to 2005 and to determine the implications of this change to the planned salt pond restoration in the region.

\section{Background and Introduction}

Key issues in the restoration of salt ponds in South San Francisco Bay are (1) whether there is enough sediment in the system to restore the salt ponds to tidal marsh and, (2) whether the increased sediment demand from restoration will result in detrimental impacts to other parts of the bay, such as loss of intertidal flats (Jaffe and Foxgrover, 2006). The history of sediment deposition and erosion within the bay can be analyzed to help answer these questions. This report presents the quantities and patterns of deposition and erosion in South San Francisco Bay from 1956 to 2005 (Fig. 1). The goal of this report is to document the historical temporal and spatial variability of deposition and erosion for specific geomorphic zones in South San Francisco Bay. These data serve as a basis for conceptual and quantitative models to predict the likelihood of successful restoration as well as potential detrimental effects resulting from the creation of sediment sinks when the ponds are opened to tidal influence. These data also provide information for evaluating the cause of deposition and erosion that has occurred during the last 49 years. During this time period numerous factors and forcings such as wind wave erosion, tidal current redistribution of sediment, changes in sediment supply from tributaries and Central Bay, and sea level rise, have altered the system. These factors and forcings will continue to alter the system as restoration proceeds. 

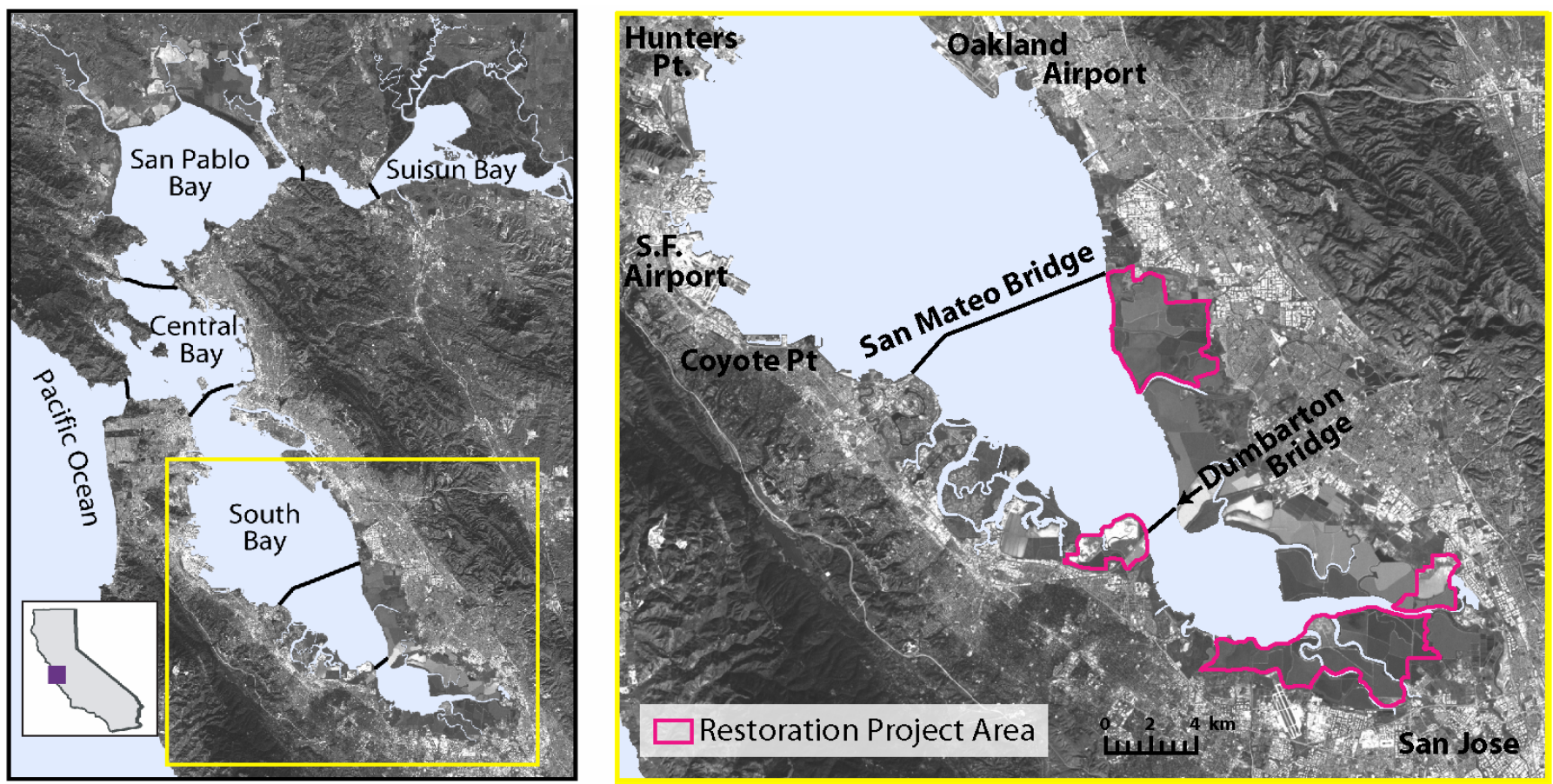

Figure 1. Location of study area showing pond complexes being considered for restoration as part of the South Bay Salt Ponds Restoration Project.

\section{Methods}

In order to quantify spatial and temporal variability of sediment distribution in South Bay over the past 49 years we modeled the surface of the bay floor for three time periods: 1956, 1983, and 2005. After the bathymetric models were adjusted to account for changing vertical datums and subsidence that occurred in the Santa Clara Valley from the 1930s to 1960s (Poland and Ireland, 1988), the grids were differenced to reveal patterns of sediment deposition and erosion.

\section{Data Sources}

Data used to create models of the bay floor, and subsequently to generate erosion and deposition grids, were collected by the National Ocean Service (NOS) branch of the National Oceanic and Atmospheric Administration (NOAA) and the California Coastal Conservancy. These data include depth soundings, shoreline location, and elevation data near the shoreline. The extent of tidal marsh was derived from topographic sheets (T-sheets) and has been displayed for visual reference.

\section{0s}

Hydrographic survey data from the 1950s covers the bay and a select number of sloughs and creeks for the region extending south from Hunters Point, approximately $420 \mathrm{~km}^{2}$ (Fig. 2). Depth soundings for the 1950s NOS surveys were collected from 1954 to 1956 and obtained digitally from the National Geophysical Data Center's (NGDC) GEOphysical DAta System for Hydrographic Survey Data (GEODAS) database (1996) (Table 1). Contours were digitized from hydrographic smooth sheets (H-sheets) and supplemented by additional hand-drawn contours based upon depth soundings to maintain a consistent contour interval throughout all of the surveys (Fig. 2). Shorelines for the 1950s surveys were digitized from $\mathrm{H}$-sheets. The marsh boundaries were digitized from scanned, georeferenced images of T-sheets obtained from the NOS Coastal Services Center.

Some soundings on H-sheet H8025 (near Hunter's Point) were missing from the GEODAS database; these soundings were manually digitized from the H-sheet and used in the surface modeling. 
Table 1. Table of 1950s H-sheets of South San Francisco Bay.

\begin{tabular}{||l|l|l|l||}
\hline \multicolumn{1}{|c|}{ H-Sheet } & \multicolumn{1}{c|}{ Year } & \multicolumn{1}{c|}{ Scale } & \multicolumn{1}{c||}{ Soundings } \\
\hline \multicolumn{4}{|c|}{} \\
\hline H8023 & 1954 & $1: 5,000$ & 7,651 \\
\hline H8024 & 1954 & $1: 10,000$ & 20,123 \\
\hline H8025 & $1954-55$ & $1: 10,000$ & 13,137 \\
\hline H8026 & $1954-55$ & $1: 10,000$ & 14,174 \\
\hline H8027 & 1955 & $1: 20,000$ & 12,900 \\
\hline H8210 & 1956 & $1: 10,000$ & 4,683 \\
\hline H8275 & 1956 & $1: 10,000$ & 15,733 \\
\hline H8281 & 1956 & $1: 10,000$ & 9,429 \\
\hline H8282 & 1956 & $1: 10,000$ & 2,918 \\
\hline & & & Total $=100,748$ \\
\hline
\end{tabular}
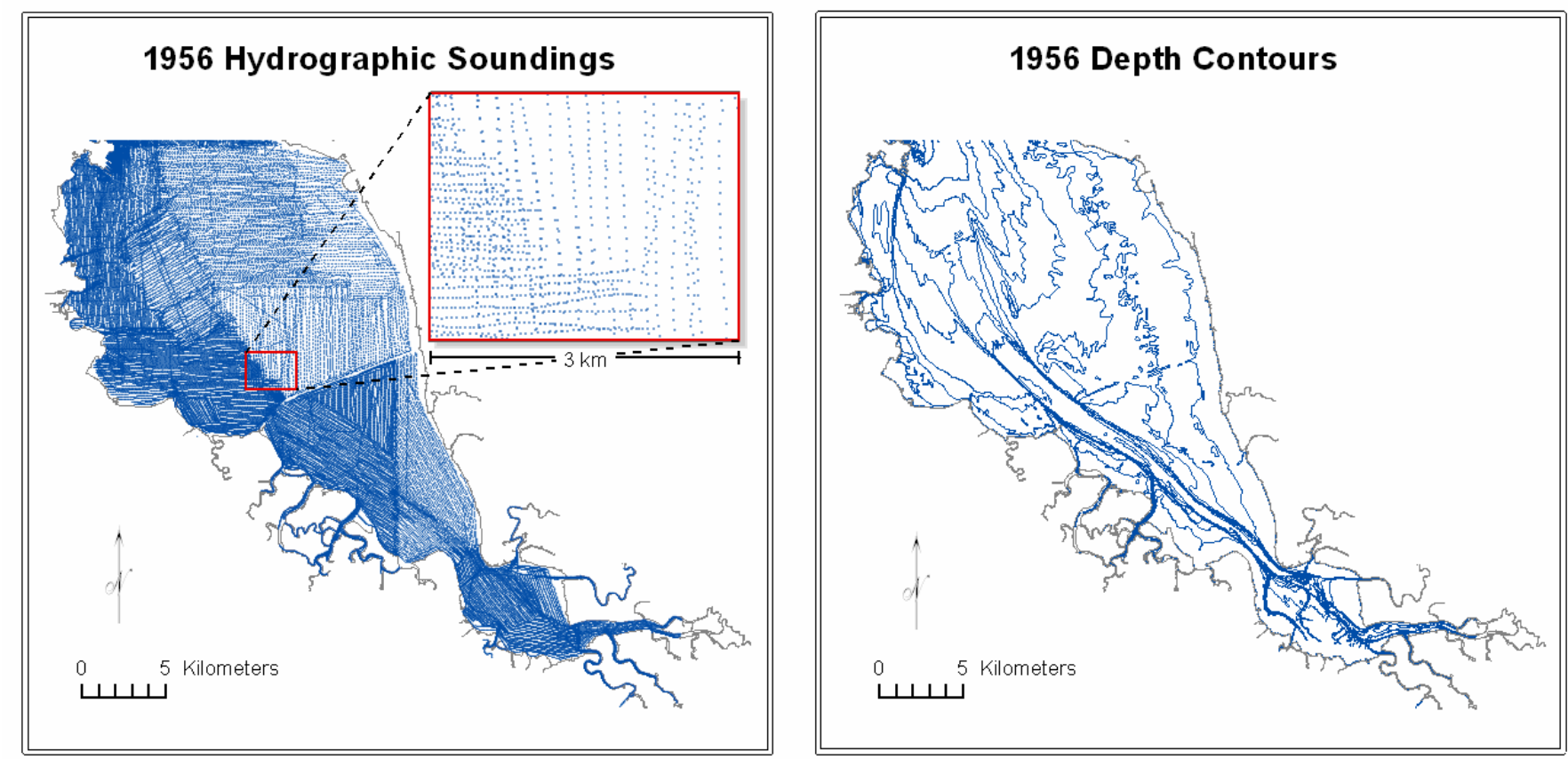

Figure 2. 1950s soundings and contours used for bay floor surface modeling.

1980s

Hydrographic survey data from the 1980 s covers the bay and a select number of sloughs, and creeks for the region extending south from Hunters Point, approximately $400 \mathrm{~km}^{2}$ (Fig. 3). Depth soundings for the 1980s surveys were collected from 1979 to 1985 and obtained digitally from NGDC's GEODAS database (National Geophysical Data Center, 1996) (Table 2). We drew contours based on depth soundings and digitized them for use in the surface modeling (Fig. 3). The shorelines as well as the marsh boundaries were obtained digitally from the San Francisco Estuary Institute (SFEI) EcoAtlas (1998).

Soundings above Mean Lower Low Water (MLLW) (intertidal soundings) for H-sheet H10132 were recorded in centimeters rather than decimeters in the GEODAS database. These points were converted from centimeters to decimeters to match the rest of the data. There was an additional cluster of approximately 30 soundings within H-sheet H10102 located near Redwood Creek whose values differed 
from their surrounding soundings by over an order of magnitude. No logical correction was evident, so these points were removed.

Table 2. Table of 1980s H-sheets of South San Francisco Bay.

\begin{tabular}{||l|l|l|l||}
\hline \multicolumn{2}{|c|}{ H-Sheet } & \multicolumn{1}{c|}{ Sear } & \multicolumn{1}{c||}{ Scale } \\
\hline \multicolumn{4}{|c|}{ Soundings } \\
\hline H9819 & 1979 & $1: 5,000$ & 19,645 \\
\hline H10102 & $1983-84$ & $1: 10,000$ & 12,600 \\
\hline H10158 & $1984-85$ & $1: 10,000$ & 5,819 \\
\hline H9869 & 1980 & $1: 10,000$ & 12,726 \\
\hline H9872 & 1980 & $1: 20,000$ & 21,356 \\
\hline H9952 & $1981-82$ & $1: 10,000$ & 22,439 \\
\hline H9984 & $1981-83$ & $1: 10,000$ & 11,413 \\
\hline H10070 & $1982-83$ & $1: 10,000$ & 12,227 \\
\hline H10132 & $1984-85$ & $1: 10,000$ & 17,870 \\
\hline
\end{tabular}
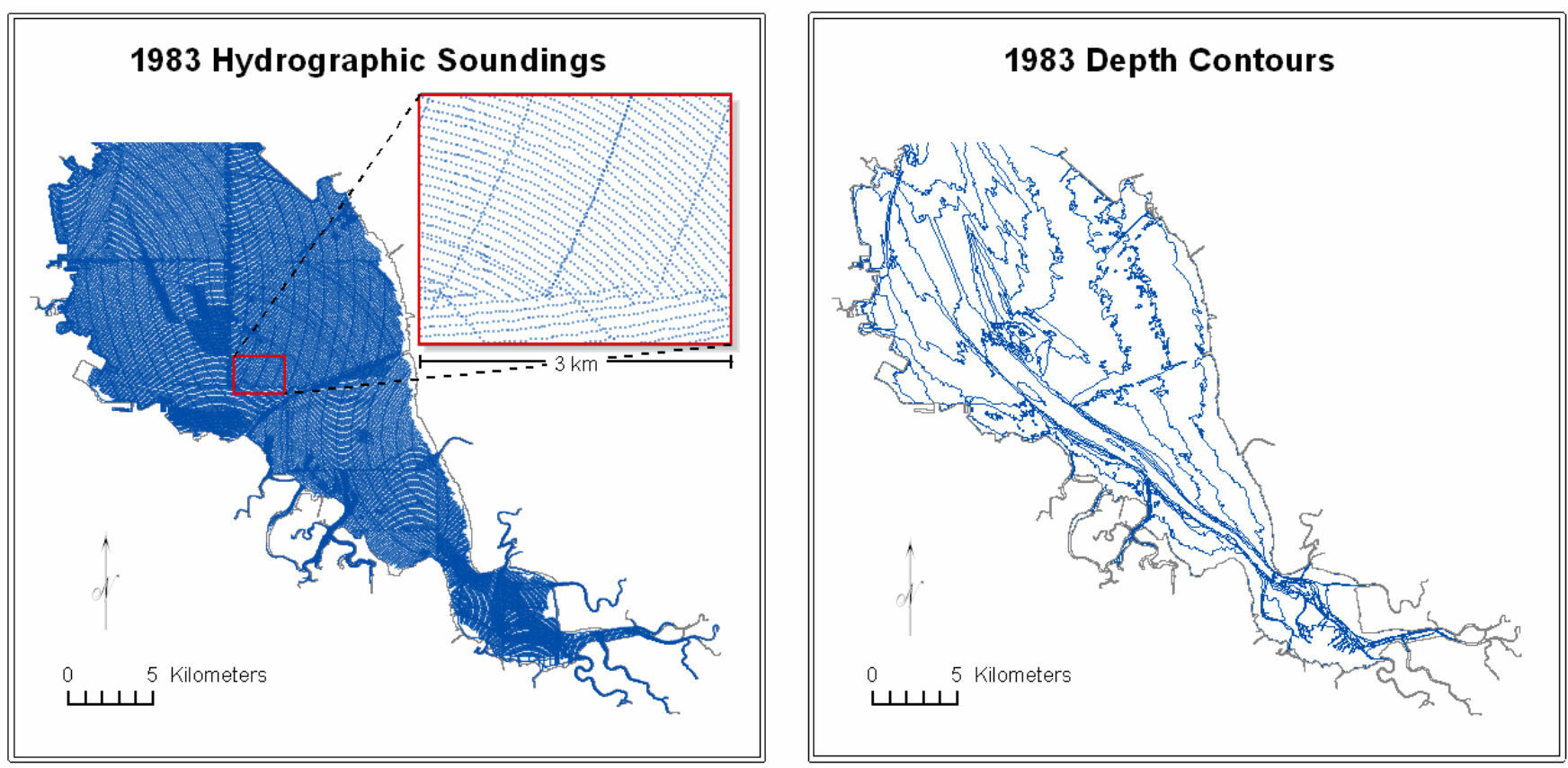

Figure 3. Soundings and contours used for 1983 bay floor surface modeling.

\section{5}

Sea Surveyor Inc. conducted a hydrographic survey of South San Francisco Bay from January 10 to April 5, 2005. The 2005 survey covers the bay and a select number of sloughs, and creeks for the region extending south from a line connecting Coyote Point on the west shore, to just south of the Oakland airport on the east shore, approximately $250 \mathrm{~km}^{2}$ (Fig. 4). Soundings were collected at a nominal spacing of $0.15 \mathrm{~m}$ along 2,600 km of trackline resulting in a total of approximately 20 million data points. Soundings decimated to $1-\mathrm{m}$ spacing (approximately 2.7 million data points) were used to model the surface of the bay floor. 
Soundings were reduced to the National Tidal Datum Epoch (NTDE) 1983-2001 MLLW at Alameda using tidal zoning developed by the NOAA Center for Operational Oceanographic Products and Services (CO-OPS). For each tidal zone, the soundings were reduced to MLLW using Alameda as the control tide station and three temporary tide gauges (San Leandro Marina, west side of San Mateo Bridge, and east side of the Dumbarton Bridge) to apply phase and amplitude corrections.

Sounding data was augmented by hand-drawn digitized depth contours drawn based upon depth soundings at an interval consistent with previous NOS surveys (Fig. 4) (Foxgrover et al., 2004). The 2005 shoreline was based on EcoAtlas data (San Francisco Estuary Institute, 1998) adjusted using data from a May 2004 topographic lidar survey (Foxgrover and Jaffe, 2005).
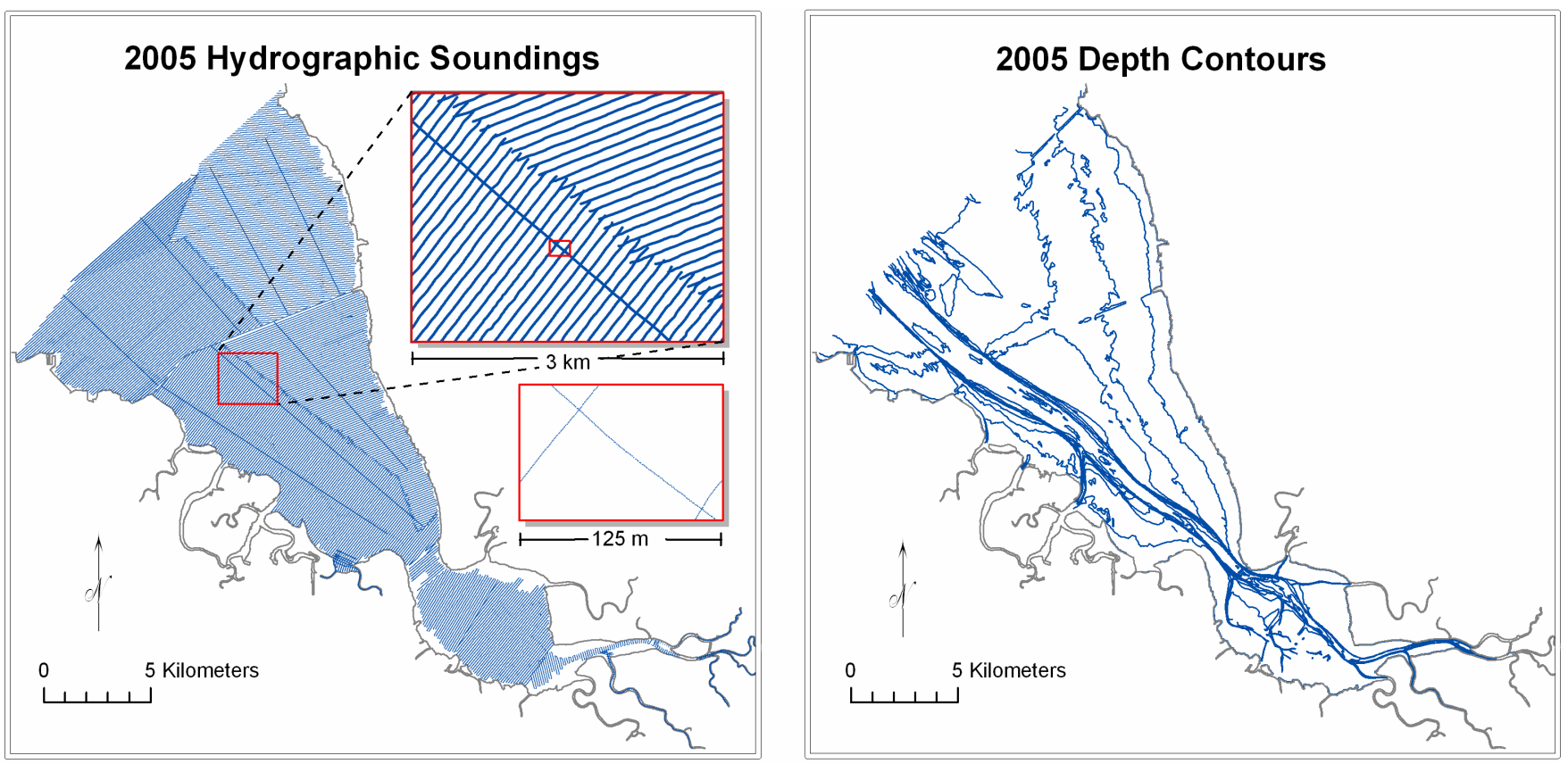

Figure 4. Soundings and contours used for 2005 bay floor surface modeling.

\section{Creation of Grids}

\section{Bathymetry Grids}

After inputting the data into a Geographic Information System (GIS), we used ArcInfo's TopoGrid module to generate a continuous surface representation of each hydrographic survey (Foxgrover et al., 2004). TopoGrid is a gridding algorithm designed to utilize both sounding and contour data to generate a hydrologically correct Digital Elevation Model (DEM). The use of contours in addition to soundings helps to better constrain the surface in areas where there is sparse data (between tracklines). TopoGrid uses an iterative finite difference interpolation technique in which the contours are initially used to build a generalized drainage model that is further refined using both soundings and contour values to determine elevation values at each cell. The 1956 and 1983 surfaces have a horizontal resolution of $50 \mathrm{~m}$ and the 2005 surface has a resolution of $25 \mathrm{~m}$. Each historical hydrographic survey is defined by more than 160,000 grid cells.

\section{Deposition and Erosion Grids}

Prior to generating the deposition and erosion grids, all of the bathymetric grids were adjusted to a common vertical datum to account for changing surveying datums accompanying fluctuations in sea level 
over the 49-year span of the surveys. All soundings are relative to the MLLW datum, which is the mean of the lower-low water heights of each tidal day observed at a control tidal station (formerly called a primary tide station) over the NTDE in use during the survey (Swanson, 1974). The NTDE is a 19-year period (18.6 year tidal epoch rounded to a full year to minimize bias from seasonal variation) that is updated approximately every 20 years to incorporate changes in the mean of MLLW caused primarily by a combination of eustatic sea level rise and land elevation change at the control tidal station (National Ocean Service, 2006). The MLLW tidal datum, therefore, varies depending upon the NTDE and the control tidal station used for the survey. Assuming no change in the bathymetry, an increase in the height of the tidal datum between surveys would result in a sounding from the later survey appearing deeper than a sounding at the same location from the earlier survey.

To determine the amount of sediment deposition and erosion, it was also necessary to account for land subsidence that occurred within the southern extent of South San Francisco Bay as a result of excessive ground water withdrawal from 1934 to 1967 (Poland and Ireland, 1988). Without correcting for subsidence, erosion would be erroneously overestimated during this time period. The degree and spatial extent of subsidence was documented in Poland and Ireland (1988). The majority of subsidence was concentrated near San Jose, approximately $16 \mathrm{~km}(10 \mathrm{mi})$ south of our study area, where subsidence

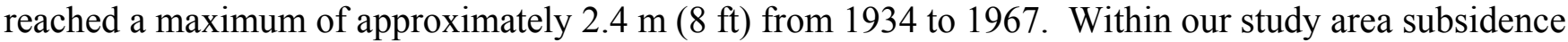

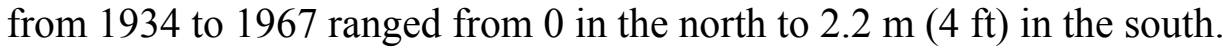

Subsidence grids were created from a surface defined by contours of equal subsidence on Poland and Ireland's (1988) 1934-1960 and 1960-1967 land subsidence maps (Figure 5) (Foxgrover et al., 2004). To define subsidence in the entire study area it was necessary to extrapolate the land subsidence contours of Poland and Ireland (1988) across the bay in the region north of the Dumbarton Bridge. Assuming linear rates for each map period, the proportion of subsidence that occurred from 1956 to 1967 was applied to the 1956 to 1983 grid of deposition and erosion. This subsidence correction accounted for approximately $9 \times 10^{6} \mathrm{~m}^{3}$ of the sediment deposited from 1956 to 1983 . We did not need to correct for subsidence for the 1983 to 2005 period because significant subsidence has not occurred within the area since about 1969 (Ingebritsen and Jones, 1999).

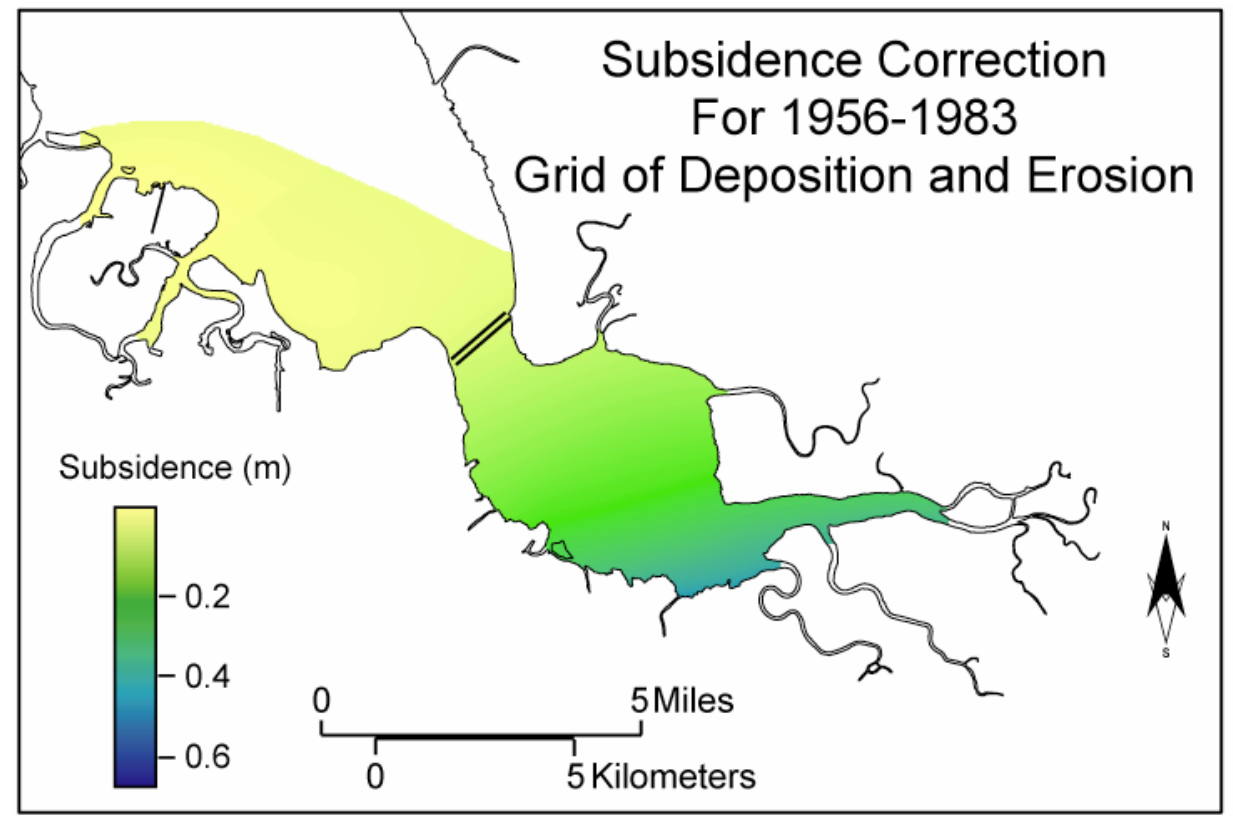

Figure 5. Subsidence corrections applied to 1956 to 1983 grid of deposition and erosion. 
After all of the adjustments were made, grids of deposition and erosion were generated by differencing the corrected bathymetric grids and, for the period from 1956 to 1983, adding the subsidence grid. Sediment volume change was calculated by multiplying the grids of deposition and erosion by the surface area in each geomorphic zone.

\section{Determination of Geomorphic Zones}

We subdivided South San Francisco Bay into geomorphically similar zones to analyze the spatial and temporal patterns of sediment deposition and erosion. The ability to link observed changes with the forcing processes, a goal of this research, is enhanced by using geomophically similar zones. The boundaries of these zones were determined using depth, slope, and breaks in slope of the bay floor as well as distinct anthropogenic artifacts such as dredge areas or sediment borrow pits. Geomorphic zones were delineated based upon the earlier year's morphology (e.g.; depths in the 1956 bathymetric model were used to determine zones for analyzing change from 1956 to 1983). The rational of using the characteristics of the earlier year to delineate zones is that it facilitates interpretation of the change (e.g.; was the shallow zone erosional or depositional). Coherent patterns of erosion or deposition and the distribution of hydrodynamic forcings, such as wind wave energy, were also used to guide the delineation of zones. The main channel system was defined as the region bounded by slopes greater than 0.3 degrees, which corresponds to the upper channel wall. Outside of the defined channel system, two breaks became apparent: one at approximately $1 \mathrm{~m}$ below MLLW and one at approximately $2 \mathrm{~m}$ below MLLW. Areas with depths less than $1 \mathrm{~m}$ (MLLW) were partitioned into shallow zones and areas with depths between $1 \mathrm{~m}$ and $2 \mathrm{~m}$ were partitioned into mid-depth zones.

\section{Error Analysis}

Two types of error are associated with the deposition and erosion grids-random error and systematic biases (HQUSACE, 2002). Bias enters from inaccuracies in determining the relation of MLLW datums used for different survey periods, from differences in rounding schemes used for recording sounding values, from methods used in the construction of subsidence grids, and from the methods used in the interpolation of the bathymetry grids. Random error is associated with sounding inaccuracy (Adams, 1942; Schallowitz, 1964; Sallenger et al., 1975). Sounding errors are assumed to be randomly distributed in space and independent of each other and therefore do not significantly affect our estimates of deposition or erosion. This assumption is supported by an analysis of the 2005 survey. The presence of non-random sounding errors was evaluated by comparing sounding values at the intersection of independent survey lines. Quality control survey lines (cross-check lines) running approximately perpendicular to the primary survey tracklines were collected as part of the 2005 hydrographic survey (Fig. 4). The mean difference of sounding values at the more than 600 survey line intersections analyzed is less than $0.01 \mathrm{~m}$.

Error in the bathymetry grids caused by the interpolation of values between soundings is a potential source of bias that is difficult to quantify. Additional factors that influence uncertainty in sediment volume change calculations derived from a series of bathymetric grids are sounding density, irregularity and relief of the terrain, and the orientation of survey tracklines relative to geomorphic features (HQUSACE 2002, from Byrnes 2002). Because the morphology of the majority of the terrain in South San Francisco Bay is relatively simple (e.g.; intertidal flats), the high sounding density, and the consistent method of grid construction, such biases are minimal. A value of $0.02 \mathrm{~m}$ of error was assigned for bias in the grids introduced by interpolation. This estimate was determined by comparing the value of individual depth soundings to the cell value of the bathymetric grid at that specific location. Differences between sounding values and grid cell values were $-0.02 \mathrm{~m}$ and less than $-0.01 \mathrm{~m}$ for the 1956 and 1983 surveys, respectively (Foxgrover et al., 2004). This is, however, only a crude estimate of the bias introduced by interpolation and does not accurately estimate the influence of interpolation algorithms in areas where no sounding data exists. 
Differences between the adopted MLLW datum for different NTDEs can introduce uncertainties when the primary control stations used to reduce soundings are unknown or if these stations change in between epochs. For the two most recent hydrographic surveys, 1983 and 2005, there is not an error associated with change in the MLLW datum because the offset in MLLW between the two epochs is known (calculated from data collected for the 1960-1978 and 1983-2001 tidal epochs at the long-term tide station at Alameda). For the 1956 hydrographic survey, soundings were reduced using the 1924-1942 tidal epoch at the San Francisco tide station (pers. comm., James Hubbard, NOS, 2005). Because the change in MLLW for the 1960-1978 to the 1983-2001 tidal epochs differs by $0.046 \mathrm{~m}$ between the San Francisco and Alameda tide stations, and we do not know the effect of using different control stations for different surveys, we are assigning a value of $0.02 \mathrm{~m}$ to this bias error.

Uncertainty in the subsidence correction derives primarily from the extrapolation of the land subsidence contours of Poland and Ireland (1988) across the bay in the region north of the Dumbarton Bridge. Our extrapolation scheme (Foxgrover et al., 2004) assumed subsidence in this region did not have strong spatial gradients (Fig. 5), which is consistent with groundwater withdrawal away from the bay and no strong structural controls in the aquifer. The lack of data in the bay only effected subsidence contours with values less than $0.15 \mathrm{~m}\left(0.5^{\prime}\right)$. We assigned a uniform $0.02 \mathrm{~m}$ value for uncertainty in our subsidence correction. This bias is only an estimate.

A bias towards erosion has been introduced to the 1956 to 1983 calculations as a result of sounding rounding conventions used in the 1950s hydrographic surveys that were not used in the 1980s surveys. For both surveys, soundings were originally recorded in feet and tenths, however, the majority of values plotted on the smooth sheets are rounded to integral feet using a shoal biased rounding scheme. The 1950s GEODAS soundings were digitized off of the H-sheets and are therefore plotted sounding values (shoal biased rounding applied). In contrast, the 1980s GEODAS soundings are the reduced sounding values (no rounding applied).

The rules for converting reduced soundings to integer values for plotting on smooth sheets are: "when rounding positive soundings to integral feet, decimals less than $0.8 \mathrm{ft}$ are disregarded; decimals of 0.8 to $0.9 \mathrm{ft}$ are increased to the next whole unit. When rounding minus soundings, decimals less than $-0.3 \mathrm{ft}$ are disregarded and decimals from -0.8 to $-0.9 \mathrm{ft}$ are treated as $-1.0 \mathrm{ft}$ " (Umbach, 1976). South San Francisco Bay 1950s hydrographic smooth sheet soundings were plotted in whole feet except for areas where a higher degree of accuracy was desirable to define depth contours, such as near the mean lower low water line and standard 3 and $6 \mathrm{ft}$ depth contours. In these regions soundings are shown to the nearest $0.5 \mathrm{ft}$ increments. Reduced decimal values from 0.3 to $0.7 \mathrm{ft}$ are shown as $0_{5}$ (representing $0.5 \mathrm{ft}$ ) for both positive and negative soundings (Umbach, 1976). As a result, the select soundings plotted in $0.5 \mathrm{ft}$ increments do not create a systematic bias because values within $\pm 0.2 \mathrm{ft}$ of the plotted value are rounded.

To approximate the amount of bias introduced through rounding, we compared the 1980s reduced soundings (not rounded) to ones we generated using the above rounding conventions. For the 139,436 soundings in the 1983 survey, rounded soundings on average were $0.07 \mathrm{~m}$ shallower than those not rounded. A complete analysis of the spatial variation of the rounding error is necessary to accurately correct this bias. Although the effect of rounding varies spatially throughout the study area, and our $+0.07 \mathrm{~m}$ value is only a rough approximation, we have used this value as an estimate of error introduced by rounding soundings. This error only applies to the 1956-1983 deposition and erosion volumes because both the 1983 and 2005 soundings were not rounded and can be compared directly after correcting for vertical datum change.

The total estimated error in our erosion and deposition volume calculations for 1956 to 1983 and 1983 to 2005 are shown in Table 3. The bias errors for soundings, grid interpolation, datum correction, and subsidence correction are added in quadrature because they are not systematic (sign of each bias is not known) (Mikhail, 1976). The estimate of total error for deposition and erosion, which includes the total non-systematic error and the error introduced by rounding of 1956 and not 1983 soundings, is 
$+0.105 /-0.035 \mathrm{~m}$ for calculations for 1956 to 1983 and $\pm 0.02 \mathrm{~m}$ for 1983 to 2005 (Table 3). This bias is treated as an error because it is spatially variable and cannot be corrected without further analyses.

Table 3. Error estimates for erosion and deposition volume calculations for South San Francisco Bay. The total non-systematic error is calculated by adding individual errors in quadrature. Comparison of rounded soundings of the 1956 surveys with un-rounded soundings from the 1980 s survey introduces a bias towards erosion. This bias creates an asymmetry in the total error with positive (deposition) error being larger than negative (erosion) error, reflecting the greater likelihood that deposition is underestimated.

\begin{tabular}{|c|c|c|}
\hline \multirow{7}{*}{$\begin{array}{l}\text { Sounding } \\
\text { Deposition and Erosion } \\
\text { Grid } \\
\text { Datum Correction } \\
\text { Subsidence Correction } \\
\text { Total non-systematic error }\end{array}$} & \multicolumn{2}{|c|}{ Estimate of Error $(\mathrm{m})$} \\
\hline & $1956-1983$ & 1983-2005 \\
\hline & 0 & 0 \\
\hline & \pm 0.02 & \pm 0.02 \\
\hline & \pm 0.02 & \pm 0.00 \\
\hline & \pm 0.02 & \pm 0.00 \\
\hline & \pm 0.035 & $\pm \mathbf{0 . 0 2 0}$ \\
\hline Rounding (shallow bias) & +0.07 & 0 \\
\hline TOTAL ERROR & $+0.105 /-0.035$ & $\pm \mathbf{0 . 0 2 0}$ \\
\hline
\end{tabular}

\section{Deposition and Erosion from 1956 to 2005}

Bathymetry and deposition and erosion in South San Francisco Bay from 1956 to 2005 are shown in Figure 6. The period from 1956 to 1983 was more erosional than from 1983 to 2005, with much of the eastern part of the bay losing sediment. Borrow pits on the 1956-1983 deposition and erosion maps appear as dark blue (erosional) straight-walled regions north of San Mateo Bridge. 


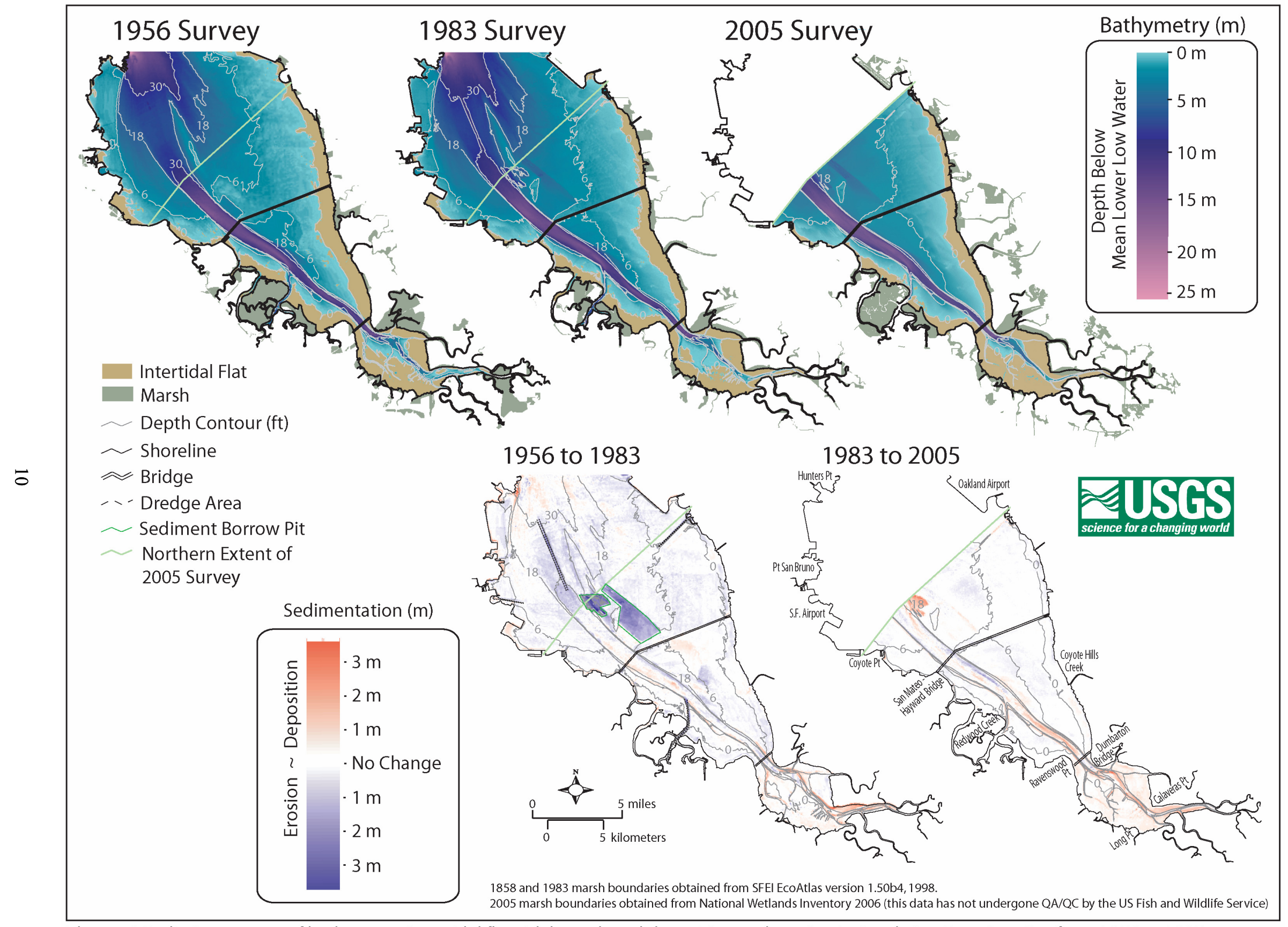

Figure 6. Preliminary maps of bathymetry, intertidal flat, tidal marsh and deposition and erosion in South San Francisco Bay from 1956 to 2005. 
a)

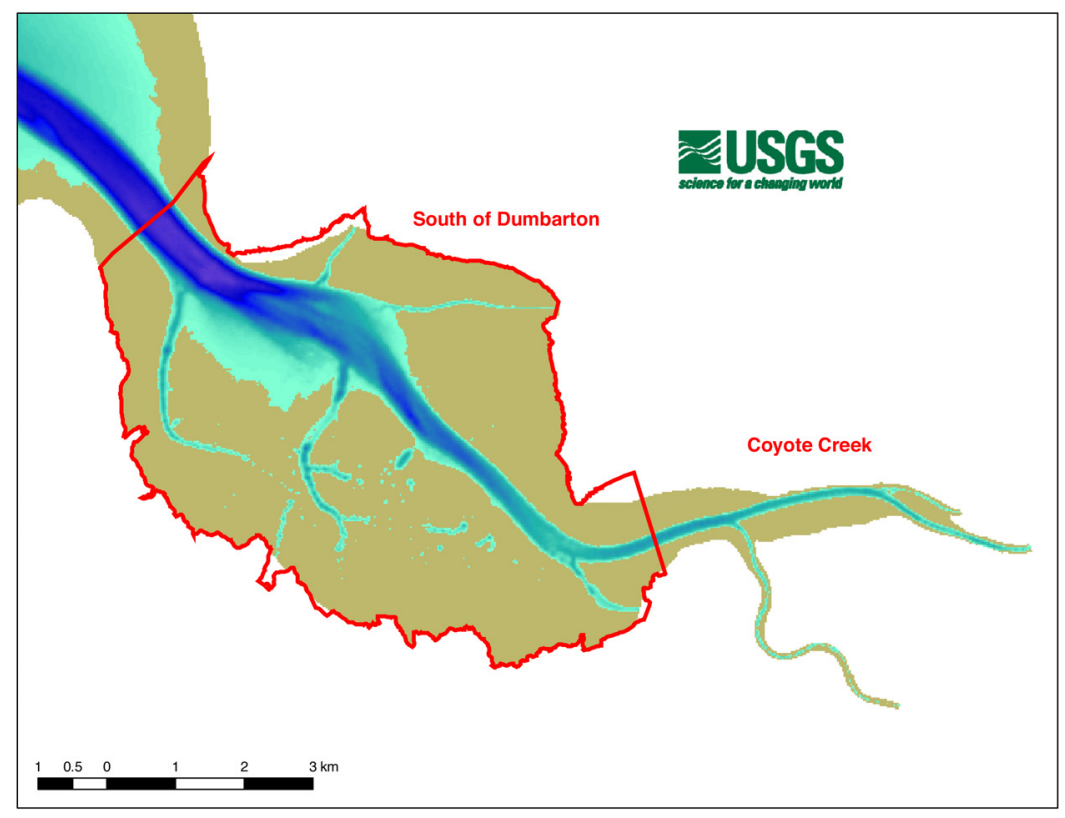

b)

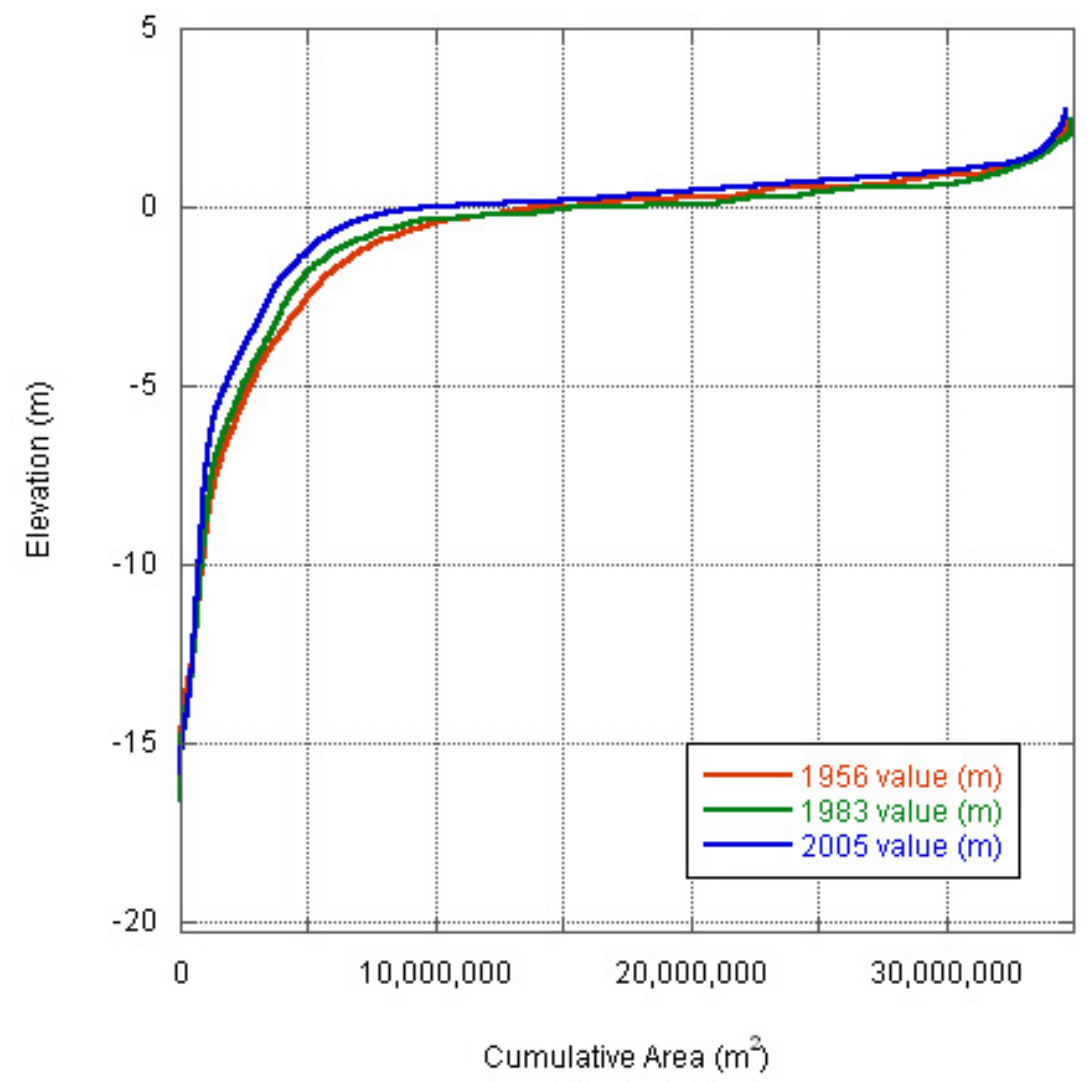

Figure 7. (a) Region for hypsometric curves shown in (b). Elevation is relative to MLLW for each survey. 
During both periods channels filled with sediment. Channel filling in the region south of the Dumbarton Bridge is illustrated by lower cumulative area values for channel depths in the hypsometric curves for the 1956, 1983, and 2005 bathymetry (Fig. 7a,b). Growth of intertidal flat area from 1983 to 2005 , which increased by approximately $35 \%$ from $17.6+2.5,-1.7 \mathrm{~km}^{2}$ to $24.2+1.8,-1.0 \mathrm{~km}^{2}$ (Jaffe and Foxgrover, 2006), is also shown in Figure 7b.

The change from an erosional system from 1956 to 1983 to a stable or depositional system from 1983 to 2005 is further illustrated by the location of the MLLW and 6 foot depth contours (Fig. 8). North of the Dumbarton Bridge, in general, the MLLW contour moves shoreward from 1956 to 1983, indicating erosion. From 1983 to 2005, in general, there was little change in the MLLW contour location, indicating only a small amount of erosion or deposition. The 6 foot depth contour exhibited similar temporal behavior as the MLLW contour. For both time periods, the region south of the Dumbarton Bridge was depositional (Figs. 6, 7b; Foxgrover et al., 2004). This pattern of greater erosion to the north and deposition to the south of the Dumbarton Bridge is consistent with net transport from north to south in the southern portion of South San Francisco Bay. The north to south transport pathway is supported by the history of intertidal flat change (Jaffe and Foxgrover, 2006).

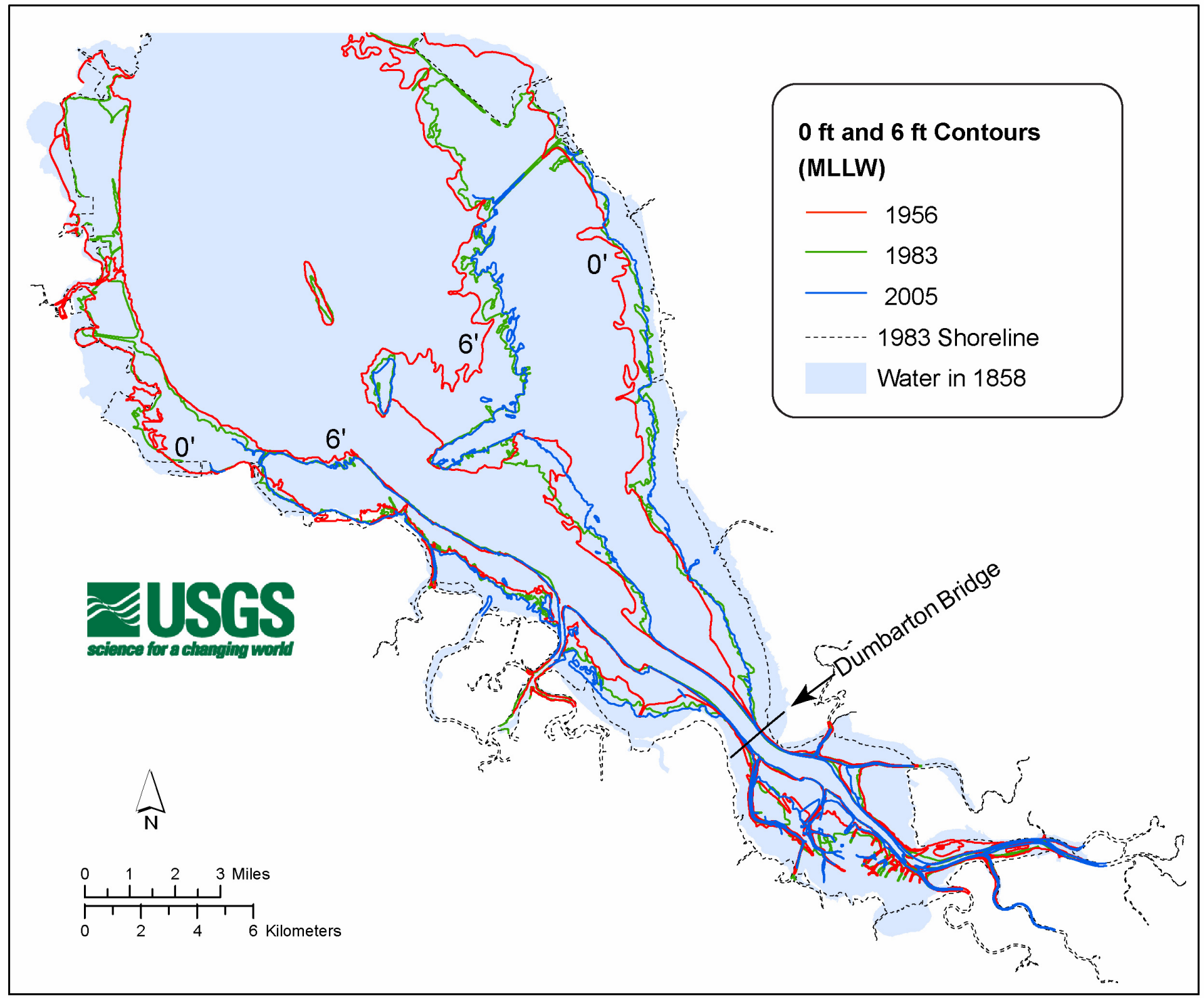

Figure 8. Change in 0 and 6 foot contour locations for 1956, 1983, and 2005 in South San Francisco Bay. 
The net volumes of deposition and erosion were calculated in selected subregions of South San Francisco Bay to explore the temporal and spatial patterns of change. A total of 16 geomorphically similar zones were defined as 11 shallow zones (shallower than $1 \mathrm{~m}$ ), 3 mid-depth zones (from $1 \mathrm{~m}$ to $2 \mathrm{~m}$ up to the channel edge), and 2 channel zones (Fig. 9). Although the same criteria were used for determining the geomorphic zones, the boundaries of the 1956-1983 zones are different than those of 1983-2005 because the morphology changed between the two time periods.

From 1956 to 1983, only the zones south of the Dumbarton Bridge experienced net deposition (Table 4, Fig. 10). Approximately $12+7.4 /-2.5 \times 10^{6} \mathrm{~m}^{3}$ of sediment was eroded from the shallows along the east shore of the bay north of the Dumbarton Bridge (E1 Shallow, E2 Shallow, E3 Shallow) at an average rate of $0.66 \pm 0.13 \mathrm{~cm} / \mathrm{yr}$. Erosion of the east shore shallows slowed from 1983 to 2005 as approximately $4 \pm 1.2 \times 10^{6} \mathrm{~m}^{3}$ of sediment was eroded at about half the rate, $0.32 \pm 0.09 \mathrm{~cm} / \mathrm{yr}$, of the previous time period (Table 4, Fig. 11).

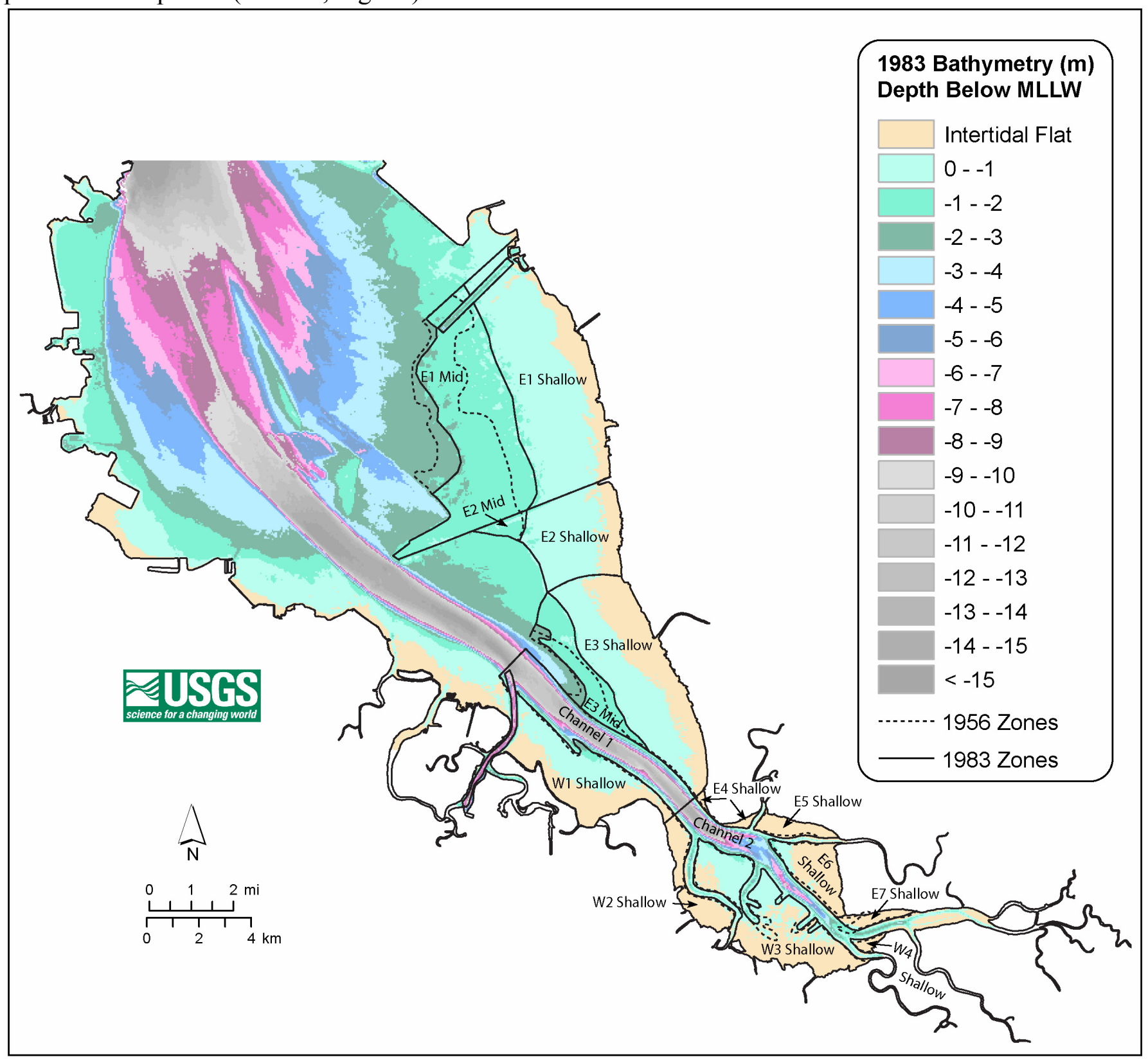

Figure 9. Boundaries for geomorphic zones overlying 1983 bathymetry. 


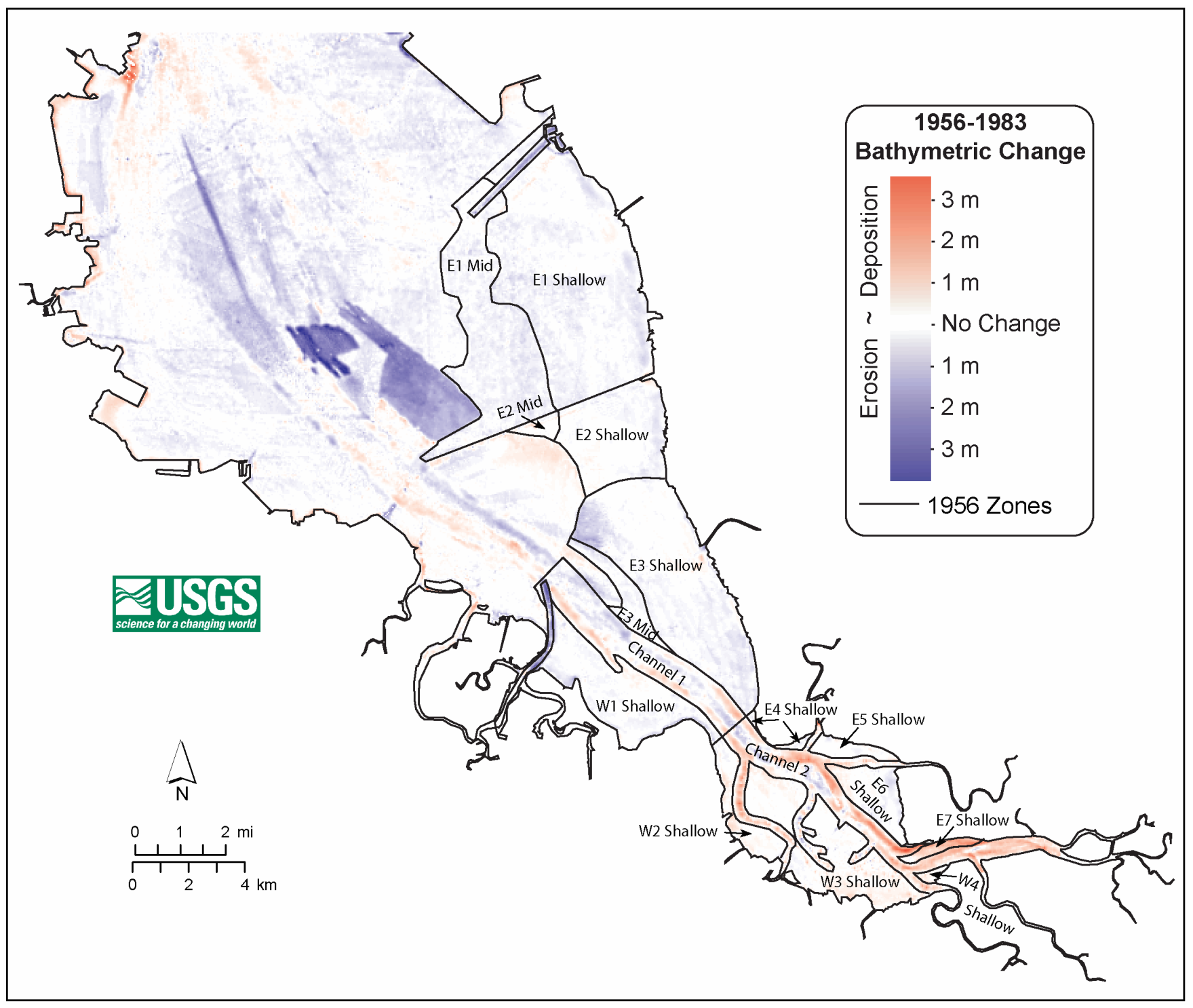

Figure 10. Boundaries for geomorphic zones overlying deposition and erosion from 1956 to 1983. 


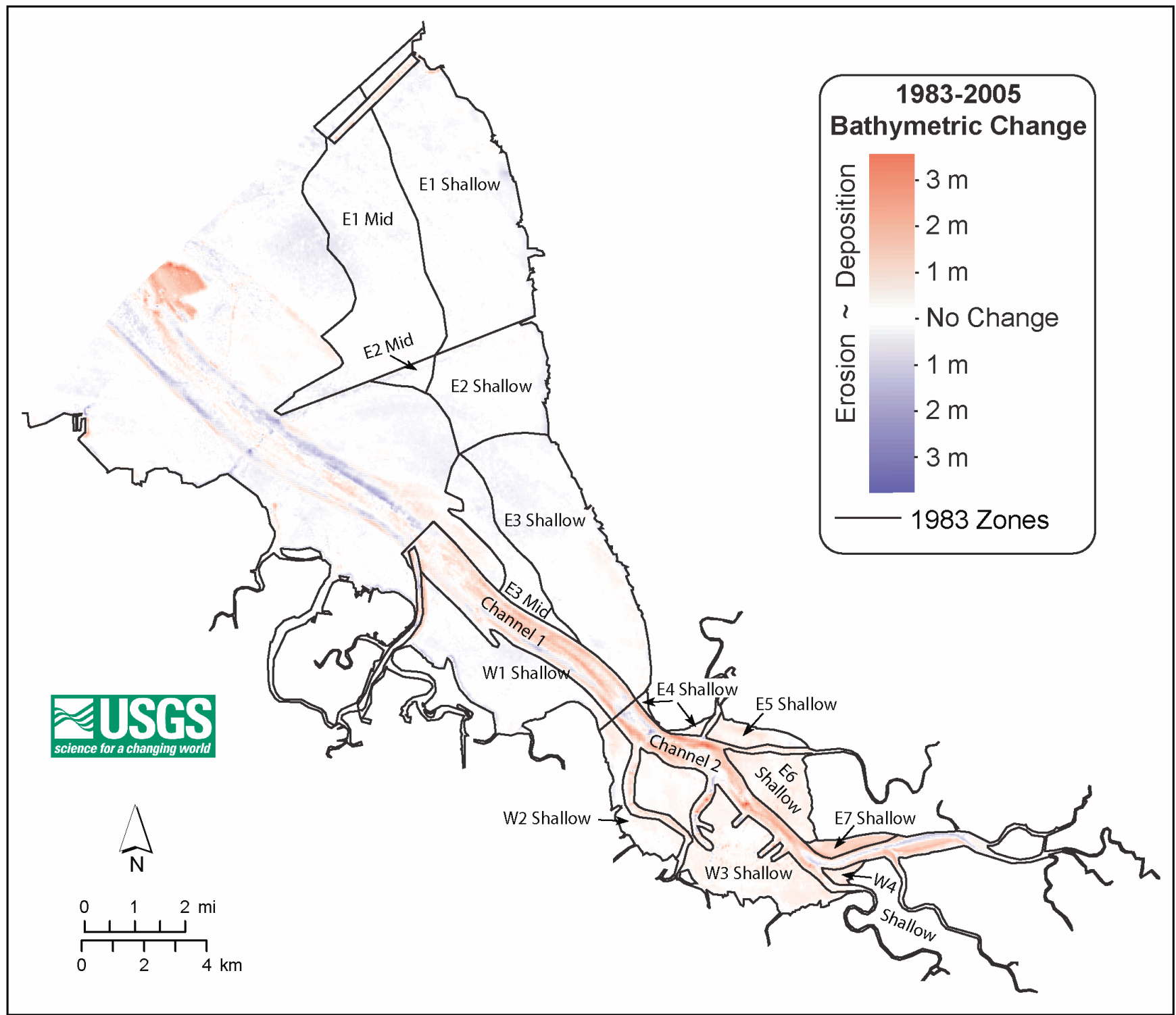

Figure 11. Boundaries for geomorphic zones overlying deposition and erosion from 1983 to 2005. 
Table 4. Deposition and erosion from 1983 to 2005 in selected regions of South San Francisco Bay. Error is calculated using $+0.105 /-0.035 \mathrm{~m}$ estimates for $1956-1983$ and $\pm 0.02 \mathrm{~m}$ for the 1983 to 2005 time period. The method for determining the error estimates is given in the Error Analysis section.

\begin{tabular}{|c|c|c|c|c|c|c|}
\hline & \multicolumn{3}{|c|}{$1956-1983$} & \multicolumn{3}{|c|}{ 1983-2005 } \\
\hline \multirow{3}{*}{$\begin{array}{l}\text { E1 Shallow } \\
\text { E2 Shallow }\end{array}$} & $\begin{array}{c}\text { Net Sediment } \\
\text { Volume Change } \\
(\mathrm{mcm})\end{array}$ & $\begin{array}{c}\text { Area } \\
\left(\mathbf{k m}^{2}\right)\end{array}$ & $\begin{array}{c}\text { Net } \\
\text { Sedimentation } \\
\text { Rate }^{1} \\
\text { (cm/yr) } \\
\end{array}$ & $\begin{array}{c}\begin{array}{c}\text { Net Sediment } \\
\text { Volume Change }\end{array} \\
(\mathrm{mcm})\end{array}$ & $\begin{array}{c}\text { Area } \\
\left(\mathrm{km}^{2}\right)\end{array}$ & $\begin{array}{c}\text { Net } \\
\text { Sedimentation } \\
\text { Rate }^{2} \\
(\mathrm{~cm} / \mathrm{yr}) \\
\end{array}$ \\
\hline & $-7.37+3.91 /-1.29$ & 36.91 & $-0.74+0.39 /-0.13$ & $-2.14 \pm 0.56$ & 28.24 & $-0.35 \pm 0.09$ \\
\hline & $-1.02+1.20 /-0.40$ & 11.35 & $-0.33+0.39 /-0.13$ & $-0.84 \pm 0.23$ & 11.39 & $-0.34 \pm 0.09$ \\
\hline E3 Shallow & $-4.39+2.53 /-0.84$ & 23.92 & $-0.68+0.39 /-0.13$ & $-1.36 \pm 0.43$ & 21.28 & $-0.29 \pm 0.09$ \\
\hline E4 Shallow & $-0.01+0.05 /-0.02$ & 0.47 & $-0.12+0.39 /-0.13$ & $0.11 \pm 0.01$ & 0.50 & $1.03 \pm 0.09$ \\
\hline E5 Shallow & $-0.01+0.17 /-0.05$ & 1.57 & $-0.02+0.39 /-0.13$ & $0.57 \pm 0.04$ & 1.77 & $1.47 \pm 0.09$ \\
\hline E6 Shallow & $-0.12+0.43 /-0.14$ & 4.05 & $-0.11+0.39 /-0.13$ & $1.69 \pm 0.09$ & 4.50 & $1.71 \pm 0.09$ \\
\hline E7 Shallow & $1.31+0.10 /-0.03$ & 0.97 & $5.01+0.39 /-0.13$ & $1.12 \pm 0.02$ & 1.08 & $4.72 \pm 0.09$ \\
\hline W1 Shallow & $-1.52+1.18 /-0.39$ & 11.11 & $-0.51+0.39 /-0.13$ & $-1.00 \pm 0.23$ & 11.50 & $-0.39 \pm 0.09$ \\
\hline W2 Shallow & $0.52+0.34 /-0.11$ & 3.22 & $0.60+0.39 /-0.13$ & $0.50 \pm 0.07$ & 3.55 & $0.64 \pm 0.09$ \\
\hline W3 Shallow & $1.85+1.27 /-0.42$ & 11.95 & $0.57+0.39 /-0.13$ & $3.38 \pm 0.25$ & 12.65 & $1.22 \pm 0.09$ \\
\hline W4 Shallow & $0.08+0.04 /-0.01$ & 0.35 & $0.82+0.39 /-0.13$ & $0.28 \pm 0.01$ & 0.47 & $2.68 \pm 0.09$ \\
\hline E1 Mid & $-4.98+2.07 /-0.68$ & 19.57 & $-0.94+0.39 /-0.13$ & $-1.86 \pm 0.50$ & 24.91 & $-0.34 \pm 0.09$ \\
\hline E2 Mid & $0.09+0.11 /-0.04$ & 1.00 & $0.35+0.39 /-0.13$ & $-0.15 \pm 0.02$ & 1.13 & $-0.59 \pm 0.09$ \\
\hline E3 Mid & $-0.66+0.33 /-0.11$ & 3.10 & $-0.79+0.39 /-0.13$ & $-0.80 \pm 0.11$ & 5.53 & $-0.66 \pm 0.09$ \\
\hline Channel 1 & $0.00+1.15 /-0.38$ & 10.84 & $0.00+0.39 /-0.13$ & $6.05 \pm 0.21$ & 10.40 & $2.64 \pm 0.09$ \\
\hline Channel 2 & $9.52+1.61 /-0.53$ & 15.22 & $2.32+0.39 /-0.13$ & $8.79 \pm 0.26$ & 13.15 & $3.04 \pm 0.09$ \\
\hline
\end{tabular}

${ }^{1} 1956$ - 1983 values include a subsidence correction and a vertical datum adjustment of $4.9 \mathrm{~cm}$ based upon the San Francisco tide station

${ }^{2} 1983$ - 2005 values include a vertical datum adjustment of $1.8 \mathrm{~cm}$ based upon Alameda tide station 
In general, the 1983-2005 period was more depositional than the 1956-1983 period everywhere in the region of this geomorphic zone analysis (Table 4). The exceptions to this are two small zones, E2 Mid and E7 Shallows. The greatest increase in deposition rates were on the shallows south of the Dumbarton Bridge (E4 Shallow, E5 Shallow, E6 Shallow, W4 Shallow), with more than $1 \mathrm{~cm} / \mathrm{yr}$ increased deposition, and the main channel north of Dumbarton (Channel 1) with more than $2.5 \mathrm{~cm} / \mathrm{yr}$ increased deposition (Table 4; Figs. 10, 11).

\section{Discussion}

A key question that needs to be addressed to predict sediment erosion and deposition in the future in South San Francisco Bay is, "Why was the period from 1983 to 2005 more depositional than the period from 1956 to 1983 ?" The pattern of net erosion in the shallows on the eastern shore north of the Dumbarton Bridge and net deposition south of the Dumbarton Bridge may provide the answer.

From 1983 to 2005, net sediment deposition for the entire region south of the Dumbarton Bridge was approximately $16 \pm 1.2 \times 10^{6} \mathrm{~m}^{3}$. Sediment input from local streams is difficult to determine because of limited data on stream sediment loads. Schoellhammer et al. (2006) estimated that the sediment load of streams discharging to the bay south of the Dumbarton Bridge is now approximately one-quarter of the 0.4

$\times 10^{6}$ tons $/ y r$ calculated by Porterfield (1980). If a sediment bulk density of $33 \mathrm{lbs} / \mathrm{ft}^{3}$ (soft mud) is used to convert from tons/yr to $\mathrm{m}^{3} / \mathrm{yr}$, the Schoellhammer et al. (2006) estimate equates to less than $0.1 \times 10^{6}$ $\mathrm{m}^{3} / \mathrm{yr}$. Even under the assumption that all the sediment from local streams was deposited South of the Dumbarton Bridge, deposition from these streams can only account for $\sim 15 \%\left(\sim 2 \times 10^{6} \mathrm{~m}^{3}\right)$ of the total net sediment deposition observed from 1983 to 2005 . Sediment must have been transported from the north into the region south of the Dumbarton Bridge.

Part of the deposition south of the Dumbarton Bridge, $4 \pm 1.2 \times 10^{6} \mathrm{~m}^{3}$, could have been supplied by erosion of the shallows on the east shore to the north. Additional sediment from the north is needed to account for the amount of net deposition observed south of the Dumbarton Bridge. South San Francisco Bay tends to be more erosional progressing south to north (Foxgrover et al., 2004). The imbalance of net deposition and sediment supply from local streams, and the pattern of greater erosion towards the north support net transport of sediment from north to south in South San Francisco Bay.

\section{Summary}

South San Francisco Bay was more depositional from 1983 to 2005 than during the preceding 27 years (from 1956 to 1983). Despite this change, three patterns were present during both periods:

(1) Net erosion in the shallows $(<1 \mathrm{~m} \mathrm{depth})$ on the eastern shore of the bay north of the Dumbarton Bridge

(2) Net deposition in the region south of the Dumbarton Bridge

(3) Filling of channels

The rates of change reflected the sediment regime of each of the time periods. During the net depositional period from 1983 to 2005, erosional areas were less erosional and depositional zones were more depositional. The cause for the increase in deposition from 1983 to 2005 is unknown. A possible explanation which is supported by the patterns of deposition and erosion and the change in rates is an increase in sediment supply from the north, as would occur if the supply from Central Bay increased from 1956-1983 to $1983-2005$.

It is clear that the sediment system of South San Francisco Bay changed from 1956 to 2005. Additional research is needed to fully understand the causes of these changes and to predict future changes and their effects on restoration of the South San Francisco Bay salt ponds. 


\section{Acknowledgements}

The California Coastal Conservancy, U.S. Geological Survey Priority Ecosystems Science program, and the San Francisco Bay Regional Water Quality Control Board supported this research. Melissa Ingraca digitized historical hydrographic and topographic surveys. Shawn Higgins contributed to georeferencing H-sheets and modeling of the bay surfaces. The NOAA Center for Operational Oceanographic Products and Services (James Hubbard, Manoj Samant, Gerald Hovis, Craig Martin and others) played a key role in the hydrographic survey by assisting in the selection of tide gauge type, loaning accurate acoustic tide gauges, determining optimum locations for tide gauges, aiding in installation of tide gauges, and in developing tidal zoning to reduce soundings to the National Tidal Datum Epoch (NTDE) 1983-2001 MLLW at Alameda. Steve Sullivan, Sea Surveyor, Inc., took great care to ensure that the 2005 bathymetric survey was as accurate as possible. This report was improved by reviews from David Finlayson and Ann Gibbs.

\section{References}

Adams, K.T., 1942. Hydrographic manual (revised ed.), U.S. Dept. of Commerce, Coast and Geodetic Survey, Special Publication 143, revised edition, 407 pp.

Byrnes, M. R., Baker, J. L., and Li, Feng, 2002, Quantifying potential measurement errors associated with bathymetric change analysis, ERDC/CHL CHETN-IV-50, U.S. Army Engineer Research and Development Center, Vicksburg, MS. [http://chl.wes.army.mil/library/publications/chetn].

Foxgrover, A.C., Higgins, S.A., Ingraca, M.K., Jaffe, B.E., and Smith, R.E., 2004, Deposition, erosion, and bathymetric change in South San Francisco Bay: 1858-1983, U.S. Geological Survey OpenFile Report 2004-1192, 25 p. [URL: http://pubs.usgs.gov/of/2004/1192]

Foxgrover, A.C. and Jaffe, B.E., 2005, South San Francisco Bay 2004 topographic lidar survey: Data overview and preliminary quality assessment, U.S. Geological Survey Open-File Report OFR2005-1284, 57 p. [URL: http://pubs.usgs.gov/of/2005/1284/]

Headquarters, U.S. Army Corps of Engineers, 2002, Hydrographic Surveying Draft Engineer Manual EM 1110-2-1003, U. S. Army Corps of Engineers, Washington, DC, 506 pp. [URL: www.usace.army.mil/publications/eng-manuals/em1110-2-1003/toc.htm.htm]

Ingebritsen, S.E., and Jones, D.R., 1999, Santa Clara Valley, California: A case of arrested subsidence: in Galloway, D., Jones, D.R., and Ingebritsen, S.E., Eds., Land Subsidence in the United States, U.S. Geological Survey Circular 1182, p. 15-22.

Jaffe, B.E. and Foxgrover, A.F., 2006, A history of tidal flat area in South San Francisco Bay, California, from 1858 to 2005, USGS Open-File Report 2006-1262, 32 p. [URL:

http://pubs.usgs.gov/of/2006/1262]

Mikhail, E. M., 1976,. Observations and least squares, Dun-Donnelley Publishing, New York, 497 pp.

National Geophysical Data Center, GEOphyscial Data System for Hydrographic Survey Data, 1996, Version 3.3, CD-ROM Set.

National Ocean Service, 2006, NOS Hydrographic Surveys Specifications and Deliverables, U.S.

Department of Commerce, Silver Spring MD, 123p. [URL:

http://chartmaker.ncd.noaa.gov/hsd/specs/specs.htm]

Poland, J.F., and Ireland, R.L. 1988, Land Subsidence in the Santa Clara Valley, California, as of 1982, U.S. Geological Survey Professional Paper 497-F, 61 p.

Poterfield, G., 1980, Sediment Transnport of Streams Tributary to San Francisco, San Pablo, and Suisun Bays, California, 1909-66, Water Resources Investigations 80-64, 92 p. 
Sallenger, A.H., Goldsmith, V., and Sutton, C.H., 1975, Bathymetric comparisons: A manual of methodology, error criteria and techniques, Special Report in Applied Marine Science and Ocean Engineering (SRAMSOE) 66, 34 pp.

San Francisco Estuary Institute, EcoAtlas, 1998, Version 1.50b4, Compact Disc.

Schalowitz, A.L., 1964. Shore and sea boundaries, U.S. Coast and Geodetic Survey Publication 10-1, v. 2, $749 \mathrm{pp}$.

Schoellhamer, D.H., Orlando, J., Wright, S.A., Freeman, L.A., 2006, Sediment supply and demand, (abs.) South Bay Science Symposium [URL:

http://www.southbayrestoration.org/pdf_files/sciencesymposium/2006ScienceSymposiumSpeakerA bstracts.pdf]

Swanson, R.L., 1974. Variability of tidal datums and accuracy in determining datums from short series of observations, National Oceanic and Atmospheric Administration Technical Report 64, 41 pp.

Umbach, M.J., 1976, Hydrographic Manual Fourth Edition, U.S. Dept. of Commerce, Coast and Geodetic Survey, 400 pp. [URL: http://www.thsoa.org/pdf/hm1976/hmall.pdf] 


\section{Contact Information}

Bruce Jaffe: bjaffe@usgs.gov

Amy Foxgrover: afoxgrover@usgs.gov

For details on the South Bay Salt Pond Restoration Project visit: http://www.southbayrestoration.org 